\title{
ANATOMICAL REVIEW OF EIRA BARBARA (CARNIVORA, MUSTELIDAE) FROM THE QUATERNARY OF SOUTHWESTERN BRAZILIAN AMAZONIA
}

\author{
PAULO RICARDO MENDONÇA LOPES \\ Laboratório de Paleontologia, Departamento de Biologia, Faculdade de Filosofia, Ciências e Letras de Ribeirão Preto, \\ Universidade de São Paulo. Av. Bandeirantes, 3900, 14040-901, Ribeirão Preto, São Paulo, Brazil. \\ pauloricardomend@gmail.com \\ MARIELA CORDEIRO DE CASTRO \\ Departamento de Ciências Biológicas, IBiotec, Universidade Federal de Goiás - Regional Catalão. \\ Av. Castelo Branco s/n, 75704-020, Catalão, Goiás, Brazil. \\ marielaccastro@yahoo.com.br \\ EDSON GUILHERME \\ Laboratório de Pesquisas Paleontológicas, Universidade Federal do Acre (Campus Rio Branco), \\ BR 364, Km 04, 69915-900, Rio Branco, Acre, Brazil. \\ guilherme@ufac.br
}

\author{
ANNIE SCHMALTZ HSIOU \\ Laboratório de Paleontologia, Departamento de Biologia, Faculdade de Filosofia, Ciências e Letras de Ribeirão Preto, \\ Universidade de São Paulo. Av. Bandeirantes, 3900, 14040-901, Ribeirão Preto, São Paulo, Brazil. \\ anniehsiou@ffclrp.usp.br
}

\begin{abstract}
Most species of mustelids currently found in South America descend from North American immigrants that arrived during the Great American Biotic Interchange, following the rise of the Isthmus of Panama. However, previous works indicate that the genus Eira arrived in South America before this event, through an island bridge in Central America. The tayra Eira barbara (Mustelidae, Carnivora), the only species of the genus, currently has a wide geographic distribution, from Mexico to northern Argentina. Here, we redescribe a fossil of E. barbara collected close to the Municipality of Marechal Thaumaturgo, Acre State, Brazil. The southwestern Brazilian Amazonia is mostly characterized by the older sediments of Solimões Formation (Neogene deposits), although on the riverbanks of the Upper Juruá River a typical Quaternary vertebrate fauna is also found, mainly represented by fossil mammals. The specimen UFAC PV-36 is a right hemimandible with the p4 preserved in situ, and it was compared to fossil and extant specimens of E. barbara, as well as with other carnivorans. The review of the fossil record shows that this taxon is restricted to the Quaternary of Brazil, in the states of Bahia, Minas Gerais and Acre, and of Argentina, in the Entre Ríos Province. In this way, our study contributes to a better understanding of the origin and distribution of the genus in the Quaternary of South America.
\end{abstract}

Keywords: Acre State, Upper Juruá River, Solimões Formation, South America, Brazil.

RESUMO - A maioria das espécies de mustelídeos atualmente encontradas na América do Sul são descendentes de imigrantes norteamericanos que chegaram durante o Grande Intercâmbio Biótico Americano, após a ascensão do Istmo do Panamá. No entanto, trabalhos prévios indicam que o gênero Eira teria chegado na América do Sul antes deste evento, através de um conjunto de ilhas na América Central. A irara Eira barbara (Mustelidae, Carnivora), a única espécie do gênero, atualmente tem uma ampla distribuição geográfica, desde o México até o norte da Argentina. Neste trabalho, redescrevemos um fóssil de E. barbara coletado em torno do Município de Marechal Thaumaturgo, Estado do Acre, Brasil. O sudoeste da Amazônia brasileira é principalmente caracterizado pelos sedimentos mais antigos da Formação Solimões (depósitos neógenos), embora nas margens do Alto Rio Juruá também é encontrada uma típica fauna de vertebrados do Quaternário, representada principalmente por fósseis de mamíferos. O material UFAC PV-36 é uma hemimandíbula direita, com o p4 preservado in situ, e foi comparado com espécimes fósseis e viventes de $E$. barbara, bem como com outros carnívoros. A revisão do registro fóssil reconhece que este táxon está restrito ao Quaternário do Brasil, nos estados da Bahia, Minas Gerais e Acre, e da Argentina, na Província de Entre Ríos Assim, nosso estudo contribui para uma melhor compreensão da origem e da distribuição do gênero no Quaternário da América do Sul.

Palavras-chave: Estado do Acre, Alto Rio Juruá, Formação Solimões, América do Sul, Brasil. 


\section{INTRODUCTION}

The fossil record indicates that the biogeographic history of mustelids is determined by numerous intercontinental dispersions, originating mainly in Eurasia, where the early fossils of the family (from the late Oligocene) were found (Wolsan, 1999; Tedford et al., 2004; Koepfli et al., 2008).

Koepfli et al. (2008) infer that paleoenvironmental and biotic changes driven by climate variations during the second half of the Neogene promoted two bursts of cladogenesis within mustelids. The first would have occurred during a $\sim 3.7$ million year interval, from the middle to late Miocene (12.5-5.8 Ma), and the second burst of diversification would have occurred during the Pliocene (5.3-1.8 Ma).

Most of the genera and species of mustelids currently found in South America descend from North American immigrants that arrived as part of the Great American Biotic Interchange (GABI), following the rise of the Isthmus of Panama, at about 3.0-2.5 Ma (Marshall \& Sempere, 1993; Coates \& Obando, 1996; Hunt, 1996; Koepfli et al., 2008). In the case of Eira, this genus is closely related to the North American extinct taxa Trigonictis and Legionarictis (see Tseng et al., 2009), corroborating this interpretation.

Based on mitochondrial data, Young (2018) reports that the process of diversification within Eira occurred at 6.3-4 Ma, coinciding with the end of the first or the beginning of the second diversification bursts detected by Koepfli et al. (2008). In this scenario, Eira would have arrived at South America earlier than other mustelids, before the complete formation of the Isthmus of Panama, coinciding with the presence of the Choco-Panama islands bridge (see Galvis, 1980). Alternatively, the rise of the Isthmus occurred earlier than most widely accepted, during the Miocene, as indicated by Montes et al. (2015).

The species Eira barbara (Linnaeus, 1758) is the only species of the genus and currently has a wide geographic distribution, from Mexico to northern Argentina (Figure 1), inhabiting tropical and subtropical forests (Reis et al., 2006; Tortato \& Althoff, 2007; Branco et al., 2013; Castro et al., 2014).

Fossils of Eira barbara in South America are relatively scarce and restricted to the Quaternary. In Brazil, the first record of the species was cited by Lund (1843), who named Galictis barbara (= Eira barbara), from the "Lapa da Escrivânia", Municipality of Lagoa Santa, in the Minas Gerais State (Figure 1A). Posteriorly, Rancy (1991) reported a specimen from the Upper Juruá River, in the Acre State (Figures 1B, 2), and Lessa et al. (1998) reported a fossil from "Gruta dos Brejões", Municipality of Morro do Chapéu, Bahia State (Figure 1C). Further reports include Castro et al. (2014), from the cave Gruta do Ioiô, Municipality of Palmeiras, Bahia State (Figure 1D), and Vasconcelos (2015), who describes a specimen found in the "Maciço Escrivânia", Municipality of Prudente de Morais, Minas Gerais State (Figure 1E). The most recent fossil record of the taxon is reported by Schiaffini et al. (2017), from Entre Ríos Province, Argentina (Figure 1F).

Although Rancy (1991) reported the fossil assigned to Eira barbara from the Upper Juruá River, Acre State, the anatomy and the taxonomic criteria used to identify the specimen were presented only briefly. Therefore, the main goal of our study is to describe the specimen UFAC-PV 36, characterizing it in a taxonomic and systematic context.

\section{MATERIAL AND METHODS}

The specimen UFAC PV-36 (Figure 3) is housed at the paleontological collection of the Laboratório de Pesquisas Paleontológicas, Universidade Federal do Acre (UFAC), Rio Branco, State of Acre, Brazil. The material is a right hemimandible with the $\mathrm{p} 4$ preserved in situ, and it was compared to fossil and extant specimens of Eira barbara, as well as with other species of carnivorans (see Appendix 1). Osteological nomenclature follows Paula-Couto (1979) and the Nomina Anatomica Veterinaria, International Committee on Veterinary Gross Anatomical Nomenclature (2012). Dental nomenclature follows Paula-Couto (1979) and Smith \& Dodson (2003). The systematic arrangement follows Bryant et al. (1993), Marmi et al. (2004) and Koepfli et al. (2008).

The material was collected near the Municipality of Marechal Thaumaturgo, southwestern Amazonia, Acre State, Brazil (Figure 2). According to Latrubesse \& Rancy (1998) and Cozzuol (2006), younger vertebrates from southwestern Brazilian Amazonia occur in several localities together with Neogene fossils, because Pleistocene terraces are developed on older Cenozoic sediments that were bisected by the same rivers that produced these terraces (Hsiou \& Albino, 2011). The Solimões Formation contains a Miocene vertebrate fauna (see Cozzuol, 2006; Bissaro-Júnior et al., 2018), while younger (Quaternary) bone-bearing conglomerates, as defined by Simpson \& Paula-Couto (1981), are exposed unconformably over this unit. The Quaternary vertebrate fauna at these localities includes mainly fossil mammals, represented by carnivorans, notoungulates, xenarthrans, proboscideans, sirenians, perissodactyls and cetartiodactyls (Simpson \& Paula-Couto, 1981; Ranzi, 2000, 2008; Hsiou \& Albino, 2011). Both fossiliferous assemblages can be found along the Upper Juruá River in the State of Acre (Latrubesse \& Rancy, 1998). The mammals recovered from Juruá River are often mixed by reworking of the deposits, hindering the establishment of specific levels in the locations (see Simpson \& Paula-Couto, 1981; Paula-Couto, 1981, 1982a, 1982b, 1983; Latrubesse \& Rancy, 1998; Ribeiro et al., 2013).

Institutional abbreviations. FUMDHAM, Fundação Museu do Homem Americano, São Raimundo Nonato, Piauí, Brazil; LPRP, Laboratório de Paleontologia de Ribeirão Preto, Faculdade de Filosofia, Ciências e Letras de Ribeirão Preto, Universidade de São Paulo, Ribeirão Preto, São Paulo, Brazil; MCL, Coleção de Paleontologia, Museu de Ciências Naturais, Pontifícia Universidade Católica de Minas Gerais, Belo Horizonte, Minas Gerais, Brazil; MCN-M, Coleção de Mastozoologia, Museu de Ciências Naturais, Pontifícia Universidade Católica de Minas Gerais, Belo Horizonte, Minas Gerais, Brazil; MNRJ, Setor de Mastozoologia, Departamento de Vertebrados, Museu Nacional, Universidade Federal do Rio de Janeiro, Rio de Janeiro, Rio de Janeiro, Brazil; MPEG, Coleção de Mastozoologia, Museu Paraense Emílio Goeldi, Belém, Pará, Brazil; MZUSP, Coleção de Mastozoologia, 


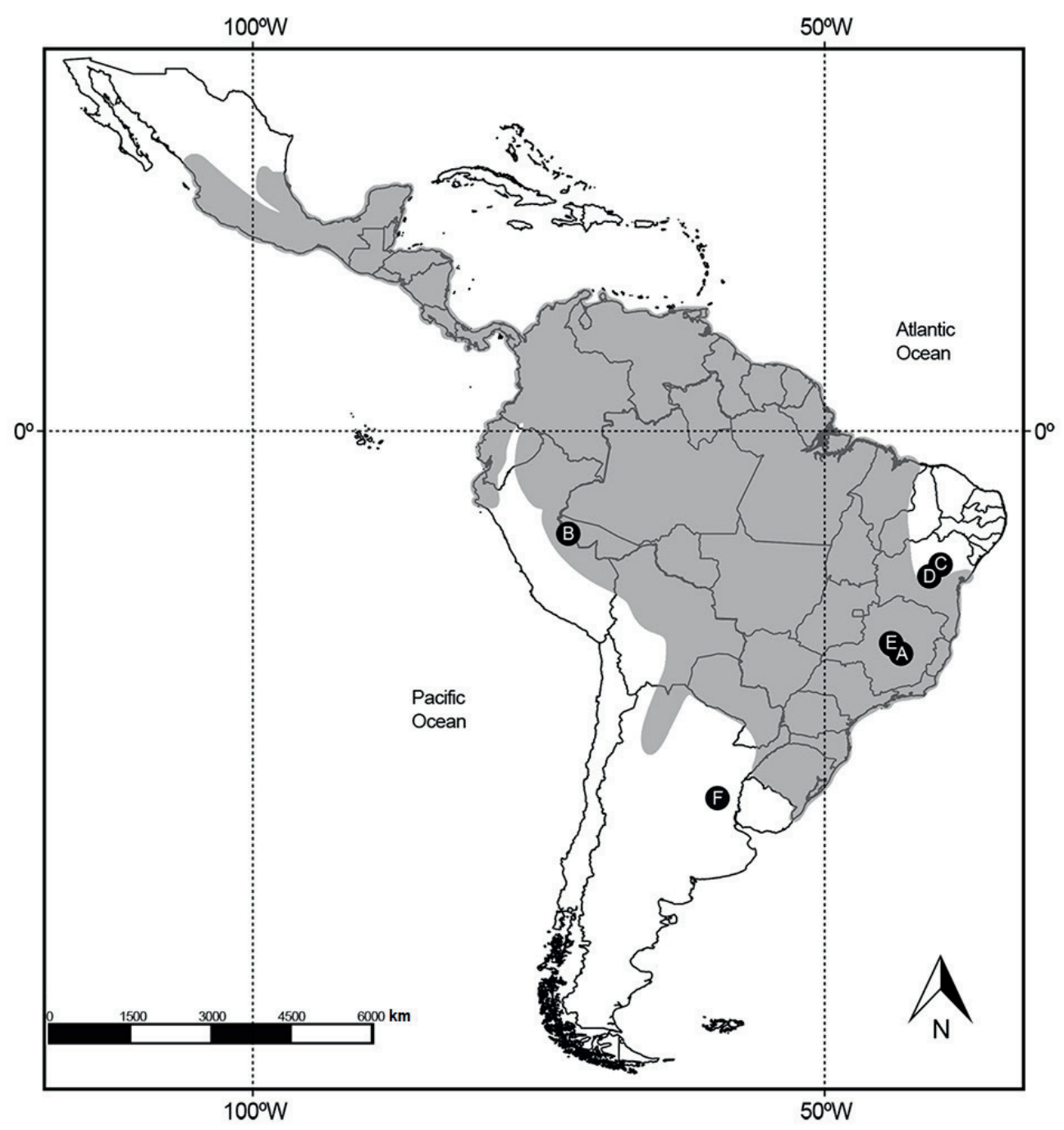

Figure 1. Records of Eira barbara in the South American Quaternary (A-F) and the current distribution of the species (gray shade). A, Lapa da Escrivânia, Lagoa Santa, Minas Gerais, Brazil; B, Upper Juruá River, Acre, Brazil; C, Gruta dos Brejões, Morro do Chapéu, Bahia, Brazil; D, Gruta do Ioiô, Palmeiras, Bahia, Brazil. E, Maciço Escrivânia, Prudente de Morais, Minas Gerais, Brazil; F, Entre Ríos Province, Argentina.

Museu de Zoologia da Universidade de São Paulo, São Paulo, São Paulo, Brazil; UFAC, Universidade Federal do Acre, Acre, Brazil; UFAC-CZM, Coleção Zoológica de Mamíferos da Universidade Federal do Acre, Rio Branco, Acre, Brazil. Anatomical abbreviations. c, lower canine; p2, second lower premolar; p3, third lower premolar; p4, fourth lower premolar; $\mathbf{m} 1$, first lower molar; $\mathbf{m} 2$, second lower molar.

\section{SYSTEMATIC PALEONTOLOGY}

MAMMALIA Linnaeus, 1758

CARNIVORA Bowdich, 1821

MUSTELOIDEA Fischer von Waldheim, 1814

MUSTELIDAE Fischer von Waldheim, 1817 GULONINAE Gray, 1825

Eira Smith, 1842

Eira barbara (Linnaeus, 1758)

(Figure 3)
Referred specimen. UFAC-PV 36, an incomplete right hemimandible with the $\mathrm{p} 4$ preserved in situ.

Locality and age. The material was collected near the Municipality of Marechal Thaumaturgo, southwestern Brazilian Amazonia, Acre State. Although the collection has not precise information about its stratigraphic origin, additional material was collected on the same terraces, allowing its attribution to the Quaternary (see Material and Methods).

Description. UFAC-PV 36 is a partial right hemimandible preserving a single premolar. It was briefly described by Rancy (1991), who referred this tooth as p3; however, the present analysis considers that it corresponds to the $\mathrm{p} 4$. Therefore, the specimen exhibits the entire $\mathrm{p} 4$ in situ and part of the root of the p3 (Figure 3). The fossil exhibits highly fragmented surfaces. The irregular aspect of fractures might be associated with transport and/or reworking of the bioclast. The presence of some rounded surfaces (at the condylar and angular processes) is probably caused by dissolution processes (Holz $\&$ Simões, 2002). The dark coloration acquired by the material 


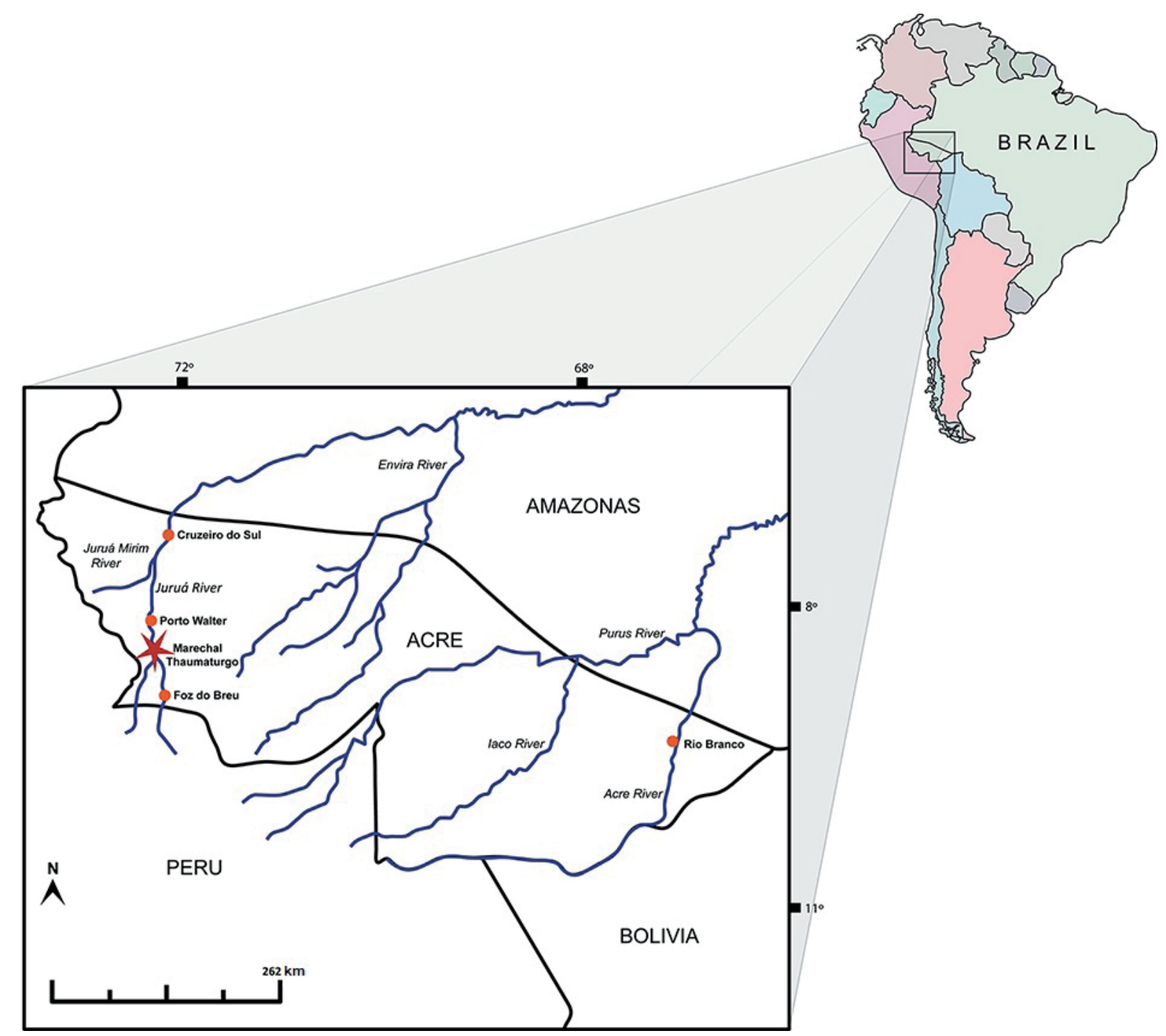

Figure 2. Acre State, southwestern Brazilian Amazonia, showing the collection site of the fossil UFAC PV-36 (red star).

was possibly the result of manganese oxide impregnation during later diagenesis (Bissaro-Júnior, pers. com.).

The ventral and dorsal margins of the mandibular body are slightly curved. In the anterior portion of the lateral surface, there are three mental foramina, which vary in size and shape (Figures 3A,D). The masseteric fossa is shallow, extending above the level of the alveolus of $\mathrm{m} 2$ and being limited by the anterior masseteric crest (Figures 3A,D). In medial view, the small mandibular foramen is posteriorly continued by an elongated groove that extends posteriorly towards the mandibular ramus. This foramen is located ventroposteriorly to the posterior margin of the alveolar process, between the angular process and the condyle (Figures 3B,E). The coronoid process and the posterior part of the condyle are broken. The angular process is curved and slightly prominent, while the angular notch is slightly curved dorsoventrally (Figures 3A,B,D,E). As the coronoid process is broken, only a small portion of the pterygoid fossa can be observed. It is shallow and dorsally limited by the alveolar process and posteroventrally by the groove that extends from the mandibular foramen (Figures 3B,E). The alveolar process extends from the posterior margin of the symphysis until the anterior margin of the coronoid process. The alveolus of $\mathrm{c}$, p2-3, and m1-2 are present, being very close to each other (Figure $3 \mathrm{C}$ ). As for its dental roots, the c, $\mathrm{p} 2$ and $\mathrm{m} 2$ are singlerooted teeth, and the p3-4 and $\mathrm{m} 1$ are two-rooted teeth. The mandibular symphysis is short and extends posteriorly to the anterior level of p2 (Figures 3B,E). The p4 (Figure 3) has a small and slightly elongated crown. The mesial cingulum is narrower and more elongated than the distal cingulum. This tooth has small fractures on the apex of the crown, distal cingulum, and tooth neck. In lateral view (Figures 3A,D), the tooth is gently convex in cross-section, differently from the medial view, where the surface appears to be slightly convex in the anterior portion and slightly depressed in the middle and posterior portions (Figures 3B,E). 
Measurements (in mm). Length from the anterior end of the mandibular symphysis to the posterior end of the condylar process: 69.7; height of the mandibular body at the distal edge of $\mathrm{m} 1: 16.2$; maximum height of $\mathrm{p} 4: 6.85$; width of $\mathrm{p} 4$ : 4.3; length of $\mathrm{p} 4: 5.5$; length of the alveolar process: 30.7 .

Morphogical and taxonomical comparisons. The fossil UFAC-PV 36 described here, as well as living specimens of Eira barbara, present morphological characteristics that resemble mainly the mandibular anatomy of Galictis vittata. However, the following characters allowed the taxonomic determination: the mandibular body of both species are slightly arched, but its height is smaller in G. vittata than in E. barbara;

A

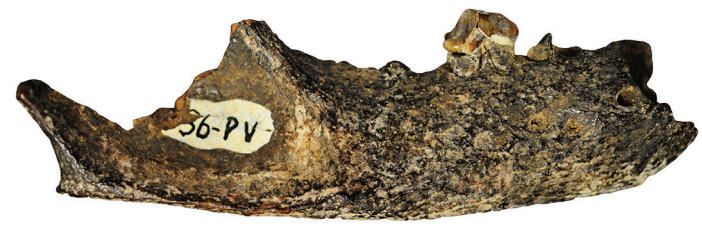

B

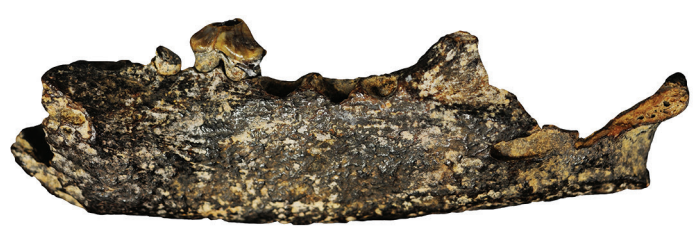

C
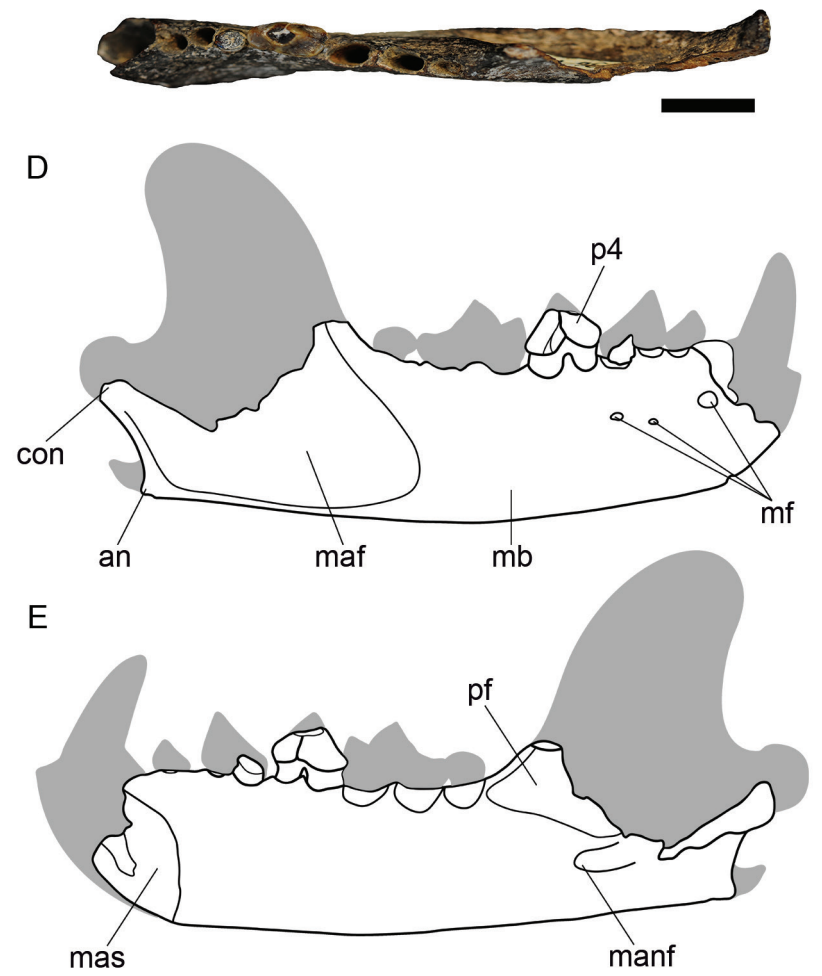

Figure 3. Right hemimandible of Eira barbara (UFAC PV-36). A, lateral view; B, medial view; $\mathbf{C}$, occlusal view; $\mathbf{D}$, schematic drawing of the lateral view; $\mathbf{E}$, schematic drawing of the medial view. The outlines in gray in figures $\mathbf{D}$ and $\mathbf{E}$ represent the missing structures of the hemimandible (UFAC PV-36) when compared to an extant adult specimen. Abbreviations: an, angular process; con, condylar process; maf, masseteric fossa; manf, mandibular foramen; mas, mandibular symphysis; mb, mandibular body; $\mathbf{m f}$, mental foramina; pf, pterygoid fossa; $\mathbf{p 4}$, fourth lower premolar. Scale bar $=1 \mathrm{~cm}$. the mandibular symphysis in $G$. vittata may extend to the distal border of p4, while in E. barbara the symphysis is restricted to the distal border of p2; the alveolar process of E. barbara shows a small space between the alveolus of $\mathrm{p} 2$ and of the canine, whereas in G. vittata this gap is absent, making the $\mathrm{p} 2$ and canine very close; the $\mathrm{p} 4$ of both species are very similar, but $G$. vittata has a much wider distal cingulum than E. barbara. Misinterpreted fossil record of Eira barbara. Two postPliocene fossils from the United States of America were misinterpreted as belonging to this taxon, under the names of "Galera perdicida" and "G. macrodon" (Cope, 1868a-c). However, after a reappraisal, G. perdicida was assigned to the genus Mephitis (Alston, 1882) and G. macrodon was attributed to Trigonictis, an intermediate form between the genus Galictis and Eira, probably in the same lineage of these two genera (Presley, 2000; Ruiz-García et al., 2013). Guérin et al. (1993) described a fossil from Toca de Cima dos Pilão from the São Raimundo Nonato, Piauí State, Brazil, with doubts about its taxonomic attribution, probably due to the high degree of fragmentation. Our analysis of photos of this specimen (FUMDHAM 19993) indicates that the mandibular and dental morphology does not agree with E. barbara; since its preservation prevents a better taxonomic assignment, it can be assigned to Musteloidea indet.

\section{FINAL CONSIDERATIONS}

The present paper describes the specimen UFAC-PV 36 from the Quaternary of Upper Juruá River, Acre, Brazil. The fossil corresponds to a right hemimandible with $\mathrm{p} 4$ preserved and assigned to Eira barbara. The revision of previous records indicate that fossils of the species are restricted to the Quaternary of Brazil, in the states of Bahia (Lessa et al., 1998; Castro et al., 2014.), Minas Gerais (Lund, 1843; Vasconcelos, 2015) and Acre (Rancy, 1991), and in Entre Ríos Province, Argentina (Schiaffini et al., 2017). Thus, the paleogeographic distribution of E. barbara was broader than the current one.

Considering that the fossils of Eira barbara known so far, including UFAC-PV 36, do not have their precise age determined, we consider a broad Quaternary age. However, although UFAC-PV 36 is a resedimented material, it was collected in situ, but reworked, we suggest that it has a Late Pleistocene age, for the following reasoning: according to Latrubesse \& Rancy (1998), the Upper Juruá River presents a Upper Pleistocene facies, defined by Simpson \& Paula-Couto (1981) as "bone-bearing conglomerate", with colors ranging from black to red-brown due to the precipitation of iron oxides; this condition is very similar to that observed in UFAC-PV 36.

Latrubesse \& Rancy (1998) point out that according to the radiocarbon ages recorded in the Ucayali, Madre de Dios and Caqueta rivers, the Pleistocene sediments deposited in the Upper Juruá River may be tentatively correlated with the Middle Pleniglacial of the Last Glaciation. For Van der Hammen \& Absy (1994), during the Middle Pleniglacial the Amazonian climate was cooler or colder and with higher rainfall, changing to a drier and markedly cold climate during the Late Pleniglacial (Latrubesse \& Rancy, 1998). 
However, the results of Latrubesse \& Rancy (1998) indicate that the climatic shift in the lowlands of the southwest of the Amazon began before the Late Pleniglacial period of the Last Glaciation. Vertebrate fossil records from Juruá River are inconclusive, as some were associated to drier savannas and other to less arid conditions (see Latrubesse \& Rancy, 1998). According to the authors, the sedimentological phase of Late Pleistocene deposition, recognized in other Amazonian rivers and associated with the climatic changes produced during deglaciation, was not identified in the Basin of Juruá River. Certainly, further stratigraphic and geochronologic works will provide a more complete paleoenvironmental frame for the Neogene and Quaternary of western Amazonia.

\section{ACKNOWLEDGMENTS}

The authors wish to thank the financial support provided by Fundação de Amparo à Pesquisa de São Paulo (FAPESP, process $n^{\circ} 2011 / 14080-0$ to ASH, process $n^{\circ} 2014 / 02005-2$ to PRML, and process n $n^{\circ}$ 2014/23815-2 to MCC), Coordenação de Aperfeiçoamento de Pessoal de Nível Superior (CAPES DS to PRML) and by Conselho Nacional de Desenvolvimento Científico e Tecnológico (CNPq, process n ${ }^{0} 309434 / 2015-7$ and 301014/2018-3 to ASH). The authors also express their gratitude to S.M. Vaz (Mastozoology Collection of Museu Nacional, UFRJ); C. Cartelle (Paleontology Collection, MCL/PUC-MG), C. Costa (Mastozoology Collection, MCL/ PUC-MG), J.P. Souza Filho and A. Maciente (Paleontology Collection, UFAC-PV), A.M. Calouro (Zoological Collection of Mammals, UFAC-CZM), J. Silva Junior (Mastozoology Collection, MPEG), M. de Vivo and J.G. Barros (Mastozoology Collection, MZUSP) for granting access to the collections under their care; E. Mayer (UNIFESSPA) for the photos of FUMDHAM 19993; and M.C. Bissaro Júnior, G.M. Cidade and S. Y. Onary-Alves (LPRP, FFCLRP/USP) for their comments and suggestions, which improved the quality of this paper. We thank L. Kerber for important informations regarding the mandibular morphology of mammals and we are grateful to F.R. Negri and A. Ranzi for informations regarding the locality of collection of the fossil redescribed here.

\section{REFERENCES}

Alston, E.R. 1882. Biologia Centrali-Americana: Mammalia. London, R.H. Porter, $220 \mathrm{p}$.

Bowdich, T.E. 1821. An analysis of the natural classifications of Mammalia for the use of students and travellers. Paris, Smith J., $115 \mathrm{p}$.

Branco, E.; Lins, F.L.M.L.; Pereira, L.C. \& Lima, A.R. 2013. Topografia do cone medular da irara (Eira barbara) e sua relevância em anestesias epidurais. Pesquisa Veterinária Brasileira, 33:813-816. doi:10.1590/S0100-736X2013000600020

Bryant, H.N.; Russel, A.P. \& Fitch, W.D. 1993. Phylogenetic relationships within the extant Mustelidae (Carnivora): appraisal of the cladistic status of the Simpsonian subfamilies. Zoological Journal of the Linnean Society, 108:301-334. doi:10.1111/j.1096-3642.1993.tb00301.x
Castro, M.C.; Montefeltro, F.C. \& Langer, M.C. 2014. The Quaternary vertebrate fauna of the limestone cave Gruta do Ioiô, northeastern Brazil. Quaternary International, 352:164-175. doi:10.1016/j.quaint.2014.06.038

Coates, A.G. \& Obando, J.A. 1996. The geological evolution of the Central American isthmus. In: J.B.C. Jackson; A.F. Budd \& A.G. Coates (eds.) Evolution and environment in tropical America, University of Chicago Press, p. 21-56.

Cope, E.D. 1868a. An addition to the vertebrate fauna of the Miocene period, with a synopsis of the extinct Cetacea of the United States. Proceedings of the Academy of Natural Sciences of Philadelphia, 19:138-156.

Cope, E.D. 1868b. Remarks on the contents of caves of southwestern Virginia. Proceedings of the Academy of Natural Sciences of Philadelphia, 19:137-138.

Cope, E.D. 1868c. Second contribution to the history of the Vertebrata of the Miocene period of the United States. Proceedings of the Academy of Natural Sciences of Philadelphia, 20:184-194.

Cozzuol, M.A. 2006. The Acre vertebrate fauna: age, diversity, and geography. Journal of South American Earth Sciences, 21:185-203. doi:10.1016/j.jsames.2006.03.005

Fischer, G. 1814. Zoognosiatabulis synopticis illustrata. $3^{\text {rd }}$ ed. Moscou, Nikolai Sergei Vsevolozsky, 732 p.

Fischer, G. 1817. Adversaria zoologica. Mémoires de la Société Impériale des Naturalistes de Moscou, 5:357-347.

Galvis, J. 1980. Un arco de islas Terciario en el Occidente colombiano. Geología Colombiana, 11:7-43.

Gray, J.E. 1825. An outline of an attempt at the disposition of Mammalia in to tribes and families, with a list of the genera apparently appertaining to each tribe. Annals of Philosophy, New Series, 10:337-344.

Guérin, C.; Curvello, M.A.; Faure, M.; Hugueney, M. \& MourerChauvire, C. 1993. La faune pléistocène du Piauí (Nordeste du Brésil): implications paléoécologiques et biochronologiques. Quaternaria Nova, 3:303-341.

Holz, M. \& Simões, M.G. 2002. Elementos fundamentais de Tafonomia. $1^{\text {st }}$ ed. Porto Alegre, Editora da Universidade Federal de Rio Grande do Sul, 231 p.

Hsiou, A.S. \& Albino, A.M. 2011. First record of Viperidae snakes from the Pleistocene of southwestern Brazilian Amazonia. Alcheringa, 35:389-395. doi:10.1080/03115518.2011.519646

Hunt, R.M. 1996. Biogeography of the order Carnivora. In: J.L. Gittleman (ed.) Carnivore behavior, ecology and evolution, Cornell University Press, p. 485-541.

International Committee on Veterinary Gross Anatomical Nomenclature. 2012. Nomina Anatomica Veterinarium. Ithaca, Cornell University, Department of Veterinary Anatomy.

Koepfli, K.P.; Deere, K.A.; Slater, G.J.; Begg, C.; Begg, K.; Grassman, L. \& Wayne, R.K. 2008. Multigene phylogeny of the Mustelidae: resolving relationships, tempo and biogeographic history of a mammalian adaptive radiation. BMC Biology, 6:10. doi:10.1186/1741-7007-6-10

Latrubesse, E.M. \& Rancy, A. 1998. The late Quaternary of the Upper Juruá River, southwestern Amazonia, Brazil: geology and vertebrate paleontology. Quaternary of South America and Antarctic Peninsula, 11:27-46.

Lessa, G.; Cartelle, C.; Helen, D.F. \& Gonçalves, P.R. 1998. Novos achados de mamíferos carnívoros do Pleistoceno final-Holoceno em grutas calcárias do Estado da Bahia. Acta Geologica Leopoldensia, 21:157-169.

Linnaeus, C. 1758. Systema naturae. $10^{\text {th }}$ ed. Estocolmo, Laurentii Salvii, 824 p. 
Lund, P.W. 1843. Blikpaa Brasiliens Dyreverdenfór Sidste Jorfomvaeltning. Femte Afthandling: Forsaettelseaf Pattedyrene. Om de nulevendeoguddode Arteraf Rovdyrenesfamilie. Copenhague, Det Kongelige Danske Videnskabernes Selskbas, $82 \mathrm{p}$.

Marmi, J.; López-Giráldez, J.F. \& Domingo-Roura, X. 2004. Phylogeny, evolutionary history and taxonomy of the Mustelidae based on sequences of the cytochrome b gene and a complex repetitive flanking region. Zoologica Scripta, 33:481-499. doi:10.1111/j.0300-3256.2004.00165.x

Marshall, L.G. \& Sempere, T. 1993.Evolution of the Neotropical Cenozoic land mammal fauna in its geochronologic, stratigraphic, and tectonic context. In: P. Goldblatt \& C.T. New Haven (eds.) Biological relationships between Africa and South America, University Press, p. 329-392.

Montes, C.; Cardona, A.; Jaramillo, C.; Pardo, A.; Silva, J.C.; Valencia, V.; Ayala, C.; Pérez-Angel, L.C.; Rodriguez-Parra, L.A.; Ramirez, V. \& Niño, H. 2015. Middle Miocene closure of the Central American seaway. Science, 348:226-229. doi:10.1126/science.aaa2815

Paula Couto, C. 1979. Tratado de Paleomastozoologia. Rio de Janeiro, Academia Brasileira de Ciências, 590 p.

Paula Couto, C. 1981. Fossil mammals from the Cenozoic of Acre, Brazil, IV. Notoungulata Notohippidae and Toxodontidae Nesodontinae. In: CONGRESO LATINO-AMERICANO DE PALEONTOLOGÍA, 2, 1981. Anais, Porto Alegre, p. 461-477.

Paula Couto, C. 1982a. Fossil mammals from the Cenozoic of Acre, Brazil. V. Notoungulata Nesodontinae (II), Toxodontinae and Haplodontheriinae, and Litopterna, Pyrotheria and Astrapotheria (II). Iheringia, Série Geologia, 7:5-43.

Paula Couto, C. 1982b. Purperia, a new name for Megahippus Paula Couto, 1981. Iheringia, Série Geologia, 7:69-70.

Paula Couto, C. 1983. Fossil mammals from the Cenozoic of Acre, Brazil. VII. Miscellanea. Iheringia, Série Geologia, 8:101-120.

Presley, S.J. 2000. Eira barbara. Mammalian Species, 636:1-6. doi:10.2307/0.636.1

Rancy, A. 1991. Pleistocene mammals and paleoecology of the western Amazon. University of Florida, Doctoral thesis, $151 \mathrm{p}$.

Ranzi, A. 2000. Paleoecologia da Amazônia: megafauna do Pleistoceno. Florianópolis, Editora da Universidade Federal de Santa Catarina, $101 \mathrm{p}$.

Ranzi, A. 2008. Paleontologia da Amazônia: mamíferos fósseis do Juruá. Rio Branco, Paim, 130 p.

Reis, N.R.; Peracchi, A.L.; Pedro, W.A. \& Lima, L.P. 2006. Mamíferos do Brasil. Londrina, Universidade Estadual de Londrina, $437 \mathrm{p}$.

Ribeiro, A.M.; Madden, R.H.; Negri, F.R.; Kerber, L.; Hsiou, A.S. \& Rodrigues, K.A. 2013. Mamíferos fósiles y biocronología en el suroeste de la Amazonia, Brasil. In: D. Brandoni \& J.I. Noriega (eds.) El Neógeno de la Mesopotamia Argentina, Buenos Aires, Asociación Paleontológica Argentina, p. 207-221 (Publicación Especial 14)

Ruiz-García, M.; Lichilín-Ortiz, N. \& Jaramillo, M.F. 2013. Molecular phylogenetics of two neotropical carnivores, Potos flavus (Procyonidae) and Eira barbara (Mustelidae): no clear existence of putative morphological subspecies. In: M. RuizGarcía \& J.M. Shostell (eds.) Molecular population genetics, evolutionary biology and biological conservation of neotropical carnivores, Nova publishers, p. 37-84.
Schiaffini, M.I.; Prevost, F.J.; Ferrero, B.S. \& Noriega, J.I. 2017. A Late Pleistocene Guloninae (Carnivora, Mustelidae) from South America (Argentina, Entre Ríos province), biogeographic implications. Journal of South American Earth Sciences, 78:141-149. doi:10.1016/j.jsames.2017.06.006

Simpson, G.G. \& Paula Couto, C. 1981. Fossil Mammal from the Cenozoic of Acre, Brazil III - Pleistocene Edentata Pilosa, Proboscidea, Sirenia, Perissodactyla and Artiodactyla. Iheringia, Série Geologia, 6:11-73.

Smith, C.H. 1842. Introduction to the Mammalia. Naturalist's Library, 13:1-299.

Smith, J.B. \& Dodson, P.A. 2003. Proposal for a standard terminology of anatomical notation and orientation in fossil vertebrate dentitions. Journal of Vertebrate Paleontology, 23:1-12.

Tedford, R.H.; Albright, L.B.; Barnosky, A.D.; FerrusquiaVillafranca, I.; Hunt, R.M.; Storer, J.; Swisher, C.C.; Voorhies, M.R.; Webb, S.D. \& Whistler, D.P. 2004. Mammalian biochronology of the Arikareean through Hemphilian interval (Late Oligocene through Early Pliocene epochs. In: M.O. Woodburne (ed.) Late Cretaceous and Cenozoic mammals of North America, Columbia University Press, p. 169-231.

Tortato, F.R. \& Althoff, S.L. 2007. Variações na coloração de iraras (Eira barbara Linnaeus, 1758 - Carnivora, Mustelidae) da Reserva Biológica Estadual do Sassafrás, Santa Catarina, sul do Brasil. Biota Neotropica, 7:365-367. doi:10.1590/S167606032007000300038

Tseng, Z.J.; Wang, X. \& Stewart, J. D. 2009. A new immigrant mustelid (Carnivora, Mammalia) from the middle Miocene Temblor Formation of central California. PaleoBios, 29:13-23.

Van der Hammen, T. \& Absy, M.L. 1994. Amazonia during the Last Glacial. Palaeogeography, Palaeoclimatology, Palaeoecology, 109:247-261. doi:10.1016/0031-0182(94)90178-3

Vasconcelos, A.G. 2015. Mamíferos quaternários da Cavidade ES08, município de Prudente de Morais, Minas Gerais: Análises tafonômica e taxonômica. Revista Brasileira de Paleontologia, 18:171-190. doi:10.4072/rbp.2015.1.12

Wolsan, M. 1999. Oldest mephitine cranium and its implications for the origin of skunks. Acta Palaeontologica Polonica, 44:223-230.

Young, Y.M. 2018. Filogeografia de la taira Eira barbara (Carnivora: Mustelidae) atraves de su rango de distribución, mediante marcadores moleculares. Facultad de Ciencias, Pontificia Universidad Javeriana, Maestria en Ciencias Biologicas, 61 p.

Received in 14 March, 2019; accepted in 11 July, 2019. 
Appendix 1. List of specimens analyzed and compared to UFAC PV-36.

\begin{tabular}{|c|c|}
\hline Species & Specimens \\
\hline Eira Barbara (extant) & $\begin{array}{l}\text { MPEG 134; MPEG 838; MPEG 276; MPEG 331; MPEG 836; MPEG 837; MPEG 1523; MPEG 1843; MPEG 4216; MPEG } \\
\text { 1208; MPEG 4218; MPEG 4247; MPEG 5510; MPEG 07900; MPEG 6519; MPEG 7112; MPEG 5621; MPEG 5622; MPEG } \\
\text { 5623; MPEG 5624; MPEG 5625; MPEG 5629; MPEG 5626; MPEG 5627; MPEG 5628; MPEG 5630; MPEG 5631; MPEG } \\
\text { 5632; MPEG 6517; MPEG 9210; MPEG 10013; MPEG 10032; MPEG 10014; MPEG 10245; MPEG 10473; MPEG 11903; } \\
\text { MPEG 20184; MPEG 22400; MPEG 22654; MPEG 6518; MNRJ 3100; MNRJ 3102; MNRJ 3106; MNRJ 3107; MNRJ 4904; } \\
\text { MNRJ 4907; MNRJ 5163; MNRJ 5512; MNRJ 5619; MNRJ 5649; MNRJ 5791; MNRJ 5959; MNRJ 5960; MNRJ 6085; MNRJ } \\
\text { 6088; MNRJ 6089; MNRJ 7611; MNRJ 10990; MNRJ 25686; MNRJ 29976; MNRJ 29977; MNRJ 30003; MNRJ 51650; MNRJ } \\
\text { 63452; MNRJ 68357; MNRJ 68358; MNRJ 68365; MNRJ 68625; MNRJ 74385; MNRJ 75096; MZUSP 468; MZUSP 144; } \\
\text { MZUSP 2469; MZUSP 3184; MZUSP 1693; MZUSP 1438; MZUSP 1087; MZUSP 22391; MZUSP 2061; MZUSP 27682; } \\
\text { MZUSP 22390; MZUSP 20192; MZUSP 22387; MZUSP 21626; MZUSP 22392; MZUSP 22389; MZUSP 22388; MZUSP } \\
\text { 2976; MZUSP 445; MZUSP 19817; MZUSP 2975; MZUSP 1807; MZUSP 19818; MZUSP 7699; MZUSP 837; MZUSP 2848; } \\
\text { MZUSP 2974; MZUSP 3760; MZUSP 1163; MZUSP 6811; MZUSP 488; MZUSP 1162; MZUSP 2924; MZUSP 1161; MZUSP } \\
\text { 2972; MZUSP 2726; MZUSP 5933; MZUSP 2237; MZUSP 2727; MZUSP 2728; MZUSP 6584; MZUSP 19814; MZUSP 3826; } \\
\text { MZUSP 4243; MZUSP 3918; MZUSP 4244; MZUSP 3917; MZUSP 4242; MZUSP 4294; MZUSP 6316; MZUSP 7029; MZUSP } \\
\text { 2653; MZUSP 5855; MZUSP 3375; MZUSP 22901; MZUSP 20056; MZUSP 20068; MZUSP 5188; MZUSP 5185; MZUSP } \\
\text { 5192; MZUSP 5191; MZUSP 19797; MZUSP 5194; MZUSP 5140; MZUSP 5193; MZUSP 926; MZUSP 5189; MZUSP 5186; } \\
\text { MZUSP 5194; MZUSP 19798; MZUSP 19809; MZUSP 19802; MZUSP 3672; MZUSP 5187; MZUSP 5275; MZUSP 19799; } \\
\text { MZUSP 19807; MZUSP 10143; MZUSP 10145; MZUSP 19806; MZUSP 10144; MZUSP 19805; MZUSP 19800; MZUSP } \\
\text { 19803; MZUSP 19808; MZUSP 19804; MZUSP 19810; MZUSP 19801; MZUSP 19845; MZUSP 5183; MCN-M 2981; MCN-M } \\
\text { 3012; MCN-M 1915; MCN-M 1987; MCN-M 1898; MCN-M 1746; MCN-M 1897; MCN-M 1745; UFAC-CZM 016; UFAC- } \\
\text { CZM 36; UFAC-CZM 154; UFAC-CZM 151. }\end{array}$ \\
\hline Eira barbara (fossil) & MCL 1849-01; MCL 21.170 01-02; LPRP 0728; FUMDAM 19993. \\
\hline Galictis vittata & MPEG 4221; MPEG 4222; MNRJ 75066. \\
\hline Galictis cuja & MPEG 22230; MPEG 22188; MNRJ 3115; MNRJ 29989. \\
\hline Lontra longicaudis & MPEG 4245; MPEG 4244; MPEG 4238; MPEG 4242; MNRJ 50799; MNRJ 50800. \\
\hline Mustela africana & MPEG 6526; MPEG 6515. \\
\hline Pteronura brasiliensis & MPEG 671; MPEG 5603; MPEG 685. \\
\hline Conepatus chinga & MPEG 22190; MPEG 22232. \\
\hline Nasua nasua & MPEG 1531; 58; MPEG 4295. \\
\hline Potos flavus & MPEG 4340; MPEG 4347. \\
\hline Procyon concrivorus & MPEG 4207; MPEG 721. \\
\hline Conepatus semistriatus & MNRJ 29990. \\
\hline Gulo gulo & MNRJ 3492. \\
\hline Musteloidea indet. & FUMDHAM 19993 \\
\hline
\end{tabular}

